\author{
Asian Journal of \\ Medical and Biological Research \\ ISSN 2411-4472 (Print) 2412-5571 (Online) \\ www.ebupress.com/journal/ajmbr
}

\title{
Article \\ Effect of foliar application of moringa leaf extract on growth and yield of late sown wheat
}

\author{
Nusrat Zahan Jhilik, Tahsina Sharmin Hoque*, Abu Zofar Md. Moslehuddin and Md. Anwarul Abedin \\ Department of Soil Science, Bangladesh Agricultural University, Mymensingh-2202, Bangladesh
}

*Corresponding author: Tahsina Sharmin Hoque, Department of Soil Science, Bangladesh Agricultural University, Mymensingh-2202, Bangladesh. E-mail: tahsinash@gmail.com

Received: 23 August 2017/Accepted: 11 September 2017/ Published: 28 September 2017

\begin{abstract}
Moringa oleifera leaf extract has a potential effect as a growth enhancer of many crops. An experiment was conducted at the Soil Science Field Laboratory of Bangladesh Agricultural University, Mymensingh, Bangladesh to evaluate the effect of foliar application of moringa leaf extract on growth and yield of late sown wheat (BARI Gom-26). The experiment was laid out in a randomized complete block design with six treatments and three replications. The treatments were $T_{1}$ (Control), $T_{2}$ [moringa leaf extract (MLE) sprayed only at tillering stage], $T_{3}$ (MLE sprayed at tillering and jointing stages), $T_{4}$ (MLE sprayed at tillering, jointing and booting stages), $\mathrm{T}_{5}$ (MLE sprayed at tillering, jointing, booting and heading stages), and $\mathrm{T}_{6}$ (MLE sprayed only at heading stage). Application of moringa leaf extract significantly increased the growth and yield attributes as well as grain and straw yield of wheat. Among various treatments with moringa leaf extract the performance of $\mathrm{T}_{4}$ (MLE sprayed at tillering, jointing and booting stages) was the best as it produced the tallest plant $(87.87 \mathrm{~cm})$, the highest fresh and dry weight of root $(16.51 \mathrm{~g}$ and $11.37 \mathrm{~g}$ respectively), the highest number of spikelets spike ${ }^{-1}(19.70)$ and filled grains spike ${ }^{-1}(45.53)$, as well as the highest grain and straw yield (3.62 t $\mathrm{ha}^{-1}$ and $5.43 \mathrm{t} \mathrm{ha}^{-1}$ respectively) of wheat. Therefore, moringa leaf extract as a foliar spray can be applied at critical growth stages to increase the growth and yield potentiality of late sown wheat.
\end{abstract}

Keywords: moringa leaf extract; foliar spray; wheat; growth; yield

\begin{abstract}
1. Introduction
Moringa (drumstick) is an important vegetable in many tropical and sub-tropical countries including Bangladesh. In Bangladesh, Moringa oleifera Lam is an important homestead species which is grown sporadically through the roadside of the northwestern region. Several researchers have indicated that moringa is a highly valued plant with multipurpose effects (Yang et al., 2006; Anwar et al., 2007; Adebayo et al., 2011; Moyo et al., 2011; Mishra et al., 2011). Moringa leaf extract (MLE) contains a miracle substance called zeatin that serves as a natural plant growth hormone along with other micronutrients that are involved in various vital plant physiological processes. It is also known to have sufficient concentration of cytokinin and gibberellic acid that are vital phytohormones, in addition to other growth-enhancing compounds such as ascorbates, phenolics, and minerals (Makkar et al., 2007). There have been earlier reports by Fuglie (2000) that the leaf extract of $M$. oleifera can accelerate growth of young plants, strengthen plants, improve resistance to pests and diseases, increase leaf duration, increase number of roots, produce more and larger fruits and generally increase yield by 20 and 35\%. MLE application can maintain optimum tissue water status and membrane stabilities, enhance antioxidant levels and activate plant defense system, increase levels of plant secondary metabolites leading to vigorous seedling growth and maximizing the crop performance (Yasmeen et al., 2012, 2013; Howladar, 2014; Rady et al., 2015).

Wheat (Triticum aestivum L.) is one of the leading cereal crops grown around the world in diverse environments. It is the second most important cereal crop in Bangladesh which has great importance in human
\end{abstract}


nutrition and industrial uses. The total area and production of wheat in Bangladesh are about 4,29,607 ha and $13,02,998$ metric tons, respectively (BBS, 2014). The average yield of wheat in this country is quite low as compared to that of other wheat growing countries of Asia like China, India, Pakistan, etc. As Bangladesh is a densely populated country, the food demand has been increasing day by day due to high population growth. In Bangladesh, wheat can be a good supplement of rice and it might play a vital role in the national economy. But wheat production is very sensitive to environmental conditions and managerial practices. Wheat is a temperature-sensitive crop and high temperature decreases its yield through physiological disorders. Late sowing is considered as a problem for low yield of wheat in Bangladesh. In late sown wheat, all the growth stages, such as tillering, flowering, and grain filling, are adversely affected by the shortened growing period. It is necessary to improve wheat production through proper fertilization and management practices.

The dependency on the use of inorganic fertilizers as a source of plant nutrients by farmers and their high cost is associated with land and soil degradation and environmental pollution (Phiri, 2010). Thus, there is continuous need to search for alternative safe natural sources of plant nutrients. Today farmers are well aware about the application of organic fertilizer to improve their crop production as well as farming land.cc In order to fill the demand of organic fertilizer, one of such option is use of MLE as fertilizer. MLE is one of such alternative, being investigated to ascertain its effect on growth and yield of crops and thus can be promoted among farmers as a possible supplement or substitute to inorganic fertilizers (Phiri, 2010). If MLE can increase the growth and yield of late sown wheat, then the potential benefit to the smallholder farmers in Bangladesh would be great because moringa is locally available. Furthermore, MLE is low-cost and environment-friendly. Although various parts of $M$. oleifera plant extracts are known to possess diverse medicinal and biological activity on human and animals, little is known scientifically about its effect as a bio-organic fertilizer on field crops. Therefore, the present study was undertaken to investigate the effect of MLE on growth and development of late sown wheat and to determine its effect on yield and yield components of the crop.

\section{Materials and Methods}

\subsection{Experimental site and soil}

The experiment was carried out at the Soil Science Field Laboratory of Bangladesh Agricultural University, Mymensingh during rabi season of 2015. The soil of the experimental site belongs to Sonatala series under the AEZ-9 (Old Brahmaputra Floodplain). The soil had silt loam texture, $\mathrm{pH}$ 6.31, organic matter content 1.15\%, total $\mathrm{N} 0.11 \%$, available $\mathrm{P} 10.98$ ppm, exchangeable $\mathrm{K} 0.25 \mathrm{me} \%$ and available $\mathrm{S} 9.78 \mathrm{ppm}$.

\subsection{Treatments}

The experiment was laid out in a Randomized Complete Block Design (RCBD) with six treatments and three replications. The treatments were $T_{1}$ (Control), $T_{2}$ (MLE sprayed only at tillering stage), $T_{3}$ (MLE sprayed at tillering and jointing stages), $\mathrm{T}_{4}$ (MLE sprayed at tillering, jointing and booting stages), $\mathrm{T}_{5}$ (MLE sprayed at tillering, jointing, booting and heading stages), and $\mathrm{T}_{6}$ (MLE sprayed only at heading stage).

\subsection{Seed sowing}

BARI Gom-26, a modern variety of wheat was used as a test crop in this experiment. Seeds were sown @ 125 $\mathrm{kg} \mathrm{ha}^{-1}$ in lines and were covered with soil by hand. The line to line distance was $25 \mathrm{~cm}$. A strip of wheat crop was established around the experimental field as border crop.

\subsection{Collection of moringa leaves and preparation of MLE}

Young leaves of moringa were harvested from young full grown trees located at different places of the Bangladesh Agricultural University campus, Mymensingh. For preparation of MLE, young leaves of about 100g were taken into a mortar with a pinch of water $(10 \mathrm{ml} / 100 \mathrm{~g}$ fresh material) and ground with a pestle. The juice was extracted by hand pressure and was filtered through the cheese cloth. The solution was re-filtered using No.2 Whatman filter paper. Following the method developed by Fuglie (2000), the extract was diluted with distilled water at a ratio of 1:32 (v/v) and then sprayed directly onto the wheat plants. The MLE was used within five hours from cutting and extracting. The prepared extract was stored at $0^{\circ} \mathrm{C}$ temperature in a refrigerator and only taken out when needed for use.

\subsection{Fertilizer application}

The full amount of triple super phosphate (TSP), muriate of potash (MoP), gypsum, zinc oxide, and boric acid were applied as the sources of $\mathrm{P}, \mathrm{K}, \mathrm{S}, \mathrm{Zn}$ and $\mathrm{B}$ at the time of final land preparation. The rates of $\mathrm{P}, \mathrm{K}, \mathrm{S}, \mathrm{Zn}$ and $\mathrm{B}$ were $20,60,10,3$, and $2 \mathrm{~kg} \mathrm{ha}^{-1}$, respectively. The recommended rate of nitrogen was $100 \mathrm{~kg} \mathrm{ha}^{-1}$ as per 
Fertilizer Recommendation Guide (BARC, 2005). To supply nitrogen, urea was applied in three equal splits. The one-third dose of urea and full dose of all other fertilizers were applied as basal to all the plots during final land preparation. The rest two thirds of urea were applied at 30 DAS (days after sowing) during crown root stage and at 56 DAS during booting stage of the crop.

\subsection{Application of MLE in the field}

An amount of $25 \mathrm{~mL}$ (application rate) of the MLE was applied per plant in the field. Hand sprayers were used to spray the extract. Control plots for $T_{1}$ treatment were remained unsprayed. The plots for $T_{2}, T_{3}, T_{4}, T_{5}$ and $T_{6}$ treatments were sprayed with MLE at different growth stages of the crop according to the treatments. Special attention was given for complete coverage of plants with spray materials.

\subsection{Intercultural operations}

Irrigation was provided at 25 and 55 DAS while the other intercultural operations such as weeding and insecticide spraying were done whenever required.

\subsection{Harvesting and collecting data}

The crop was harvested at full maturity. The grain yield was obtained on $14 \%$ moisture basis while the straw yield was recorded on sun dry basis. Five hills were selected randomly from each plot and data on growth and yield components including plant height, root length, fresh and dry weight of root, spike length, number of spikelets spike $^{-1}$, number of grains spike ${ }^{-1}$ and 1000-grain weight were recorded.

\subsection{Statistical analysis}

The collected data were analyzed statistically by F-test to examine the treatment effects and the mean differences were adjudged by Duncan's New Multiple Range Test (Gomez and Gomez, 1984).

\section{Results and Discussion}

\subsection{Effect of moringa leaf extract on growth components of late sown wheat (BARI Gom-26)}

Application of moringa leaf extract had significant effects on the growth parameters of late sown wheat viz. plant height, fresh and dry weight of root plant ${ }^{-1}$ while the root length remained significantly unaffected (Table 1). The highest values for plant height $(87.87 \mathrm{~cm})$, root length $(15.96 \mathrm{~cm})$, fresh weight of root $(16.51 \mathrm{~g})$ and dry weight of root plant ${ }^{-1}(11.37 \mathrm{~g})$ were recorded from treatment $\mathrm{T}_{4}$ where moringa extract was sprayed at tillering, jointing and booting stages. The lowest values for plant height $(79.80 \mathrm{~cm})$, root length $(12.07 \mathrm{~cm})$, fresh weight of root $(9.04 \mathrm{~g})$ and dry weight of root $(5.88 \mathrm{~g})$ were obtained from control treatment $\left(\mathrm{T}_{1}\right)$ where no moringa leaf extract was applied. All the growth parameters were increased with the increase of the frequency of moringa leaf extract application at critical vegetative growth stages. Our results are in agreement with those of Abbas $e t$ al. (2013) and Ali et al. (2011) who suggested increased plant height and improved fresh and dry weight of wheat root by applying moringa leaf extract compared to control. Previously Foidle (2001) revealed that spraying of moringa leaf extract to many field crops can strengthen plants, promote the vegetative growth and increase the weight of root.

Table 1. Growth parameters of wheat under different treatments.

\begin{tabular}{lllll}
\hline Treatments & Plant height $(\mathbf{c m})$ & Root length $(\mathbf{c m})$ & Fresh weight of root $(\mathbf{g})$ & Dry weight of root $(\mathbf{g})$ \\
\hline $\mathrm{T}_{1}$ & $79.80 \mathrm{~b}$ & 12.07 & $9.04 \mathrm{~d}$ & $5.88 \mathrm{~b}$ \\
$\mathrm{~T}_{2}$ & $80.67 \mathrm{~b}$ & 13.17 & $12.41 \mathrm{c}$ & $9.93 \mathrm{a}$ \\
$\mathrm{T}_{3}$ & $86.97 \mathrm{a}$ & 13.63 & $14.58 \mathrm{~b}$ & $8.90 \mathrm{ab}$ \\
$\mathrm{T}_{4}$ & $87.87 \mathrm{a}$ & 15.96 & $16.51 \mathrm{a}$ & $11.37 \mathrm{a}$ \\
$\mathrm{T}_{5}$ & $82.80 \mathrm{~b}$ & 14.80 & $14.83 \mathrm{~b}$ & $9.13 \mathrm{ab}$ \\
$\mathrm{T}_{6}$ & $83.00 \mathrm{~b}$ & 13.57 & $10.67 \mathrm{~d}$ & $6.65 \mathrm{~b}$ \\
$\mathrm{SE}( \pm)$ & 0.94 & 0.47 & 0.83 & 0.65 \\
$\mathrm{CV}(\%)$ & 2.57 & 13.43 & 5.14 & 17.89 \\
\hline
\end{tabular}

Figures in a column having common letter(s) do not differ significantly.

$\mathrm{CV}=\mathrm{Co}$-efficient of variation

$\mathrm{SE}=$ Standard error of means 
Treatment details: $T_{1}=$ Control (foliar spray with water), $T_{2}=$ MLE sprayed only at tillering stage, $T_{3}=$ MLE sprayed at tillering and jointing stages, $\mathrm{T}_{4}=$ MLE sprayed at tillering, jointing and booting stages, $\mathrm{T}_{5}=$ MLE sprayed at tillering, jointing, booting and heading stages, $\mathrm{T}_{6}=$ MLE sprayed only at heading stage.

\subsection{Effect of moringa leaf extract on yield components of wheat}

Yield components of wheat including number of spikelets spike ${ }^{-1}$, number of filled grains spike ${ }^{-1}$ and number of unfilled grains spike ${ }^{-1}$ were significantly affected by different treatments while the spike length and 1000-grain weight remained significantly unaffected (Table 2). Similar with the results for growth parameters, the yield components of wheat improved with the frequency of applying moringa leaf extract. The performance of treatment $\mathrm{T}_{4}$ (MLE sprayed at tillering, jointing and booting stages) was the best as it produced the highest number of spikelets spike ${ }^{-1}(19.70)$, number of filled grains spike ${ }^{-1}$ (45.53), highest spike length $(12.92 \mathrm{~cm})$ and 1000 -grain weight (40.02 g). For all the yield components, the performance of the control treatment $\left(\mathrm{T}_{1}\right)$ was poor. Chattha et al. $(2015)$, and Yasmeen et al. $(2013,2012)$ also found the increased grain weight plant ${ }^{-1}$ due to application of moringa leaf extract.

Table 2. Yield parameters of wheat under different treatments.

\begin{tabular}{|c|c|c|c|c|c|}
\hline Treatments & $\begin{array}{l}\text { Spike length } \\
\text { (cm) }\end{array}$ & $\begin{array}{l}\text { Number of } \\
\text { spikelets spike }^{-1}\end{array}$ & $\begin{array}{l}\text { Number of filled } \\
\text { grains spike }\end{array}$ & $\begin{array}{l}\text { Number of } \\
\text { unfilled grains } \\
\text { spike }^{-1}\end{array}$ & $\begin{array}{l}\text { 1000-grain } \\
\text { weight (g) }\end{array}$ \\
\hline $\mathrm{T}_{1}$ & 9.95 & $16.67 \mathrm{c}$ & $35.80 \mathrm{~d}$ & $3.83 \mathrm{a}$ & 33.37 \\
\hline $\mathrm{T}_{2}$ & 10.7 & $17.93 \mathrm{bc}$ & $40.37 \mathrm{~cd}$ & $2.77 \mathrm{~b}$ & 35.54 \\
\hline $\mathrm{T}_{3}$ & 10.88 & $17.93 \mathrm{bc}$ & $42.93 \mathrm{~b}$ & $2.73 \mathrm{~b}$ & 37.24 \\
\hline $\mathrm{T}_{4}$ & 12.92 & $19.70 \mathrm{a}$ & $45.53 \mathrm{a}$ & $1.93 \mathrm{~b}$ & 40.02 \\
\hline $\mathrm{T}_{5}$ & 10.42 & $18.19 \mathrm{~b}$ & $42.27 \mathrm{bc}$ & $2.43 \mathrm{~b}$ & 39.75 \\
\hline $\mathrm{T}_{6}$ & 10.00 & $17.74 \mathrm{bc}$ & $41.33 \mathrm{c}$ & $2.57 \mathrm{~b}$ & 34.38 \\
\hline $\mathrm{SE}( \pm)$ & 0.26 & 0.26 & 0.77 & 0.19 & 0.59 \\
\hline CV $(\%)$ & 4.62 & 3.91 & 6.93 & 20.82 & 2.11 \\
\hline
\end{tabular}

Figures in a column having common letter(s) do not differ significantly.

$\mathrm{CV}=$ Co-efficient of variation

$\mathrm{SE}=$ Standard error of means

Treatment details: $T_{1}=$ Control (foliar spray with water), $T_{2}=$ MLE sprayed only at tillering stage, $T_{3}=$ MLE sprayed at tillering and jointing stages, $\mathrm{T}_{4}=$ MLE sprayed at tillering, jointing and booting stages, $\mathrm{T}_{5}=$ MLE sprayed at tillering, jointing, booting and heading stages, $\mathrm{T}_{6}=$ MLE sprayed only at heading stage.

\subsection{Effect of moringa leaf extract on yield of BARI Gom-26}

The result of this study reveals that grain yield as well as straw yield of wheat was significantly influenced due to application of moringa leaf extract (Table 3). The grain yield ranged from 2.26 to $3.62 \mathrm{t} \mathrm{ha}^{-1}$ whereas the straw yield ranged from 3.92 to $5.43 \mathrm{t} \mathrm{ha}^{-1}$. For both grain and straw yields, the maximum values were observed in treatment $\mathrm{T}_{4}$ (MLE sprayed at tillering, jointing and booting stages) and the minimum values were found in control treatment $\left(T_{1}\right)$. The highest values for grain and straw yields as found in $T_{4}$ were statistically similar to the yields obtained in $\mathrm{T}_{5}$ (MLE sprayed at tillering, jointing, booting and heading stages). For grain yield as well as straw yield, different treatments may be ranked in the order of $T_{4}>T_{5}>T_{6}>T_{3}>T_{2}>T_{1}$. Furthermore, the percent increase in yield of wheat over control due to different treatments ranged from 19.08 to 38.16 for grain and 17.86 to 38.52 for straw. For both grain and straw yield, treatments $T_{4}$ and $T_{2}$ gave the highest and the lowest yield increase over control, respectively.

These findings corroborate with the results of Mathew (2016), Culver et al. (2013) and Yasmeen et al. (2012) who obtained better crop yields by applying moringa leaf extract. Moreover, Afzal et al. (2015) suggested that $3 \%$ moringa leaf juice applied as a foliar spray at critical growth stages (tillering and booting stages) has the potential to increase the grain yield of late-sown wheat. Recently Ahmad et al. (2016) stated that 3\% moringa leaf extract (MLE) significantly enhanced the yield through improvement of crop growth. The improvement in growth and yield of crop at foliar application of MLE might be due to the presence of growth promoting substances as well as nutrient elements in moringa as suggested by many reseachers (Siddhuraju and Becker, 2003; Anwar et al., 2007; Jacob and Shenbagaraman 2011; Abdalla 2013). 
Table 3. Effect of moringa leaf extract on the yield of BARI Gom-26.

\begin{tabular}{lllll}
\hline Treatments & ${\text { Grain yield }\left(\mathbf{t ~ h a}^{-\mathbf{1}}\right)}$ & \% increase in grain yield & Straw yield $\left(\mathbf{t ~ h a}^{-\mathbf{1}}\right)$ & \% increase in straw yield \\
\hline $\mathrm{T}_{1}$ & $2.62 \mathrm{c}$ & - & $3.92 \mathrm{c}$ & - \\
$\mathrm{T}_{2}$ & $3.12 \mathrm{~b}$ & 19.08 & $4.62 \mathrm{~b}$ & 17.86 \\
$\mathrm{~T}_{3}$ & $3.14 \mathrm{~b}$ & 19.84 & $4.71 \mathrm{~b}$ & 20.15 \\
$\mathrm{~T}_{4}$ & $3.62 \mathrm{a}$ & 38.16 & $5.43 \mathrm{a}$ & 38.52 \\
$\mathrm{~T}_{5}$ & $3.45 \mathrm{ab}$ & 31.67 & $4.83 \mathrm{~b}$ & 23.21 \\
$\mathrm{~T}_{6}$ & $3.17 \mathrm{~b}$ & 20.99 & $4.75 \mathrm{~b}$ & 21.17 \\
$\mathrm{SE}( \pm)$ & 0.09 & - & 0.14 & - \\
$\mathrm{CV}(\%)$ & 4.74 & - & 4.8 & - \\
\hline
\end{tabular}

Figures in a column having common letter (s) do not differ significantly

$\mathrm{CV}=$ Co-efficient of variation

$\mathrm{SE}=$ Standard error of means

Treatment details: $\quad T_{1}=$ Control (foliar spray with water), $T_{2}=$ MLE sprayed only at tillering stage, $T_{3}=$ MLE sprayed at tillering and jointing stages, $\mathrm{T}_{4}=$ MLE sprayed at tillering, jointing and booting stages, $\mathrm{T}_{5}=$ MLE sprayed at tillering, jointing, booting and heading stages, $\mathrm{T}_{6}=$ MLE sprayed only at heading stage

\subsection{Correlation between grain yield and plant parameters}

Grain yield is a complex character that resulted from the interaction of many plant growth parameters and yield contributing characters like plant height, root length, number of spikelets spike ${ }^{-1}$, number of filled and unfilled grains spike $^{-1}$, spike length, and 1000-grain weight. In order to observe the interrelationship among the plant characters studied, a correlation matrix was done. The correlation matrix between grain yield and growth characters of wheat are summarized in (Table 4). Plant height was significantly correlated with grain yield $(\mathrm{r}=$ $\left.0.504^{*}\right)$ and root length $\left(\mathrm{r}=0.566^{*}\right)$. Root length was significantly correlated with plant height $\left(\mathrm{r}=0.566^{*}\right)$. Fresh weight of root was significantly correlated with grain yield $\left(\mathrm{r}=0.529^{*}\right)$ and dry weight of root $(\mathrm{r}$ $\left.=0.850^{* *}\right)$. Again, Table 5 indicates the correlation matrix between grain yield and yield parameters of wheat. The spike length was significantly correlated with number of spikelets $\operatorname{spike}^{-1}\left(\mathrm{r}=0.518^{*}\right)$ and 1000-grain weight $\left(\mathrm{r}=0.541^{*}\right)$. The number of spikelets spike ${ }^{-1}$ was significantly correlated with grain yield $\left(\mathrm{r}=0.756^{* *}\right)$, number of filled grains spike ${ }^{-1}\left(\mathrm{r}=0.844^{* *}\right)$ and 1000-grain weight $\left(\mathrm{r}=0.618^{* *}\right)$. The number of filled grains spike $^{-1}$ was significantly correlated with number of spikelets $\operatorname{spike}^{-1}\left(\mathrm{r}=0.844^{* *}\right)$, 1000-grain weight $(\mathrm{r}$ $\left.=0.687^{* *}\right)$ and grain yield $\left(\mathrm{r}=0.665^{* *}\right)$. The 1000 -grain weight was significantly correlated with spike length $(\mathrm{r}$ $=0.541 *)$, number of spikelets spike ${ }^{-1}\left(\mathrm{r}=0.618^{* *}\right)$ and number of filled grains spike ${ }^{-1}(\mathrm{r}=0.687 * *)$. The overall correlation matrix indicated that grain yield was positively correlated with the plant height $(\mathrm{r}=0.504 *)$, number of spikelets spike $\left(\mathrm{r}=0.765^{* *}\right)$, number of filled grains $\operatorname{spike}^{-1}\left(\mathrm{r}=0.665^{* *}\right)$, fresh weight of root $\left(\mathrm{r}=0.529^{*}\right)$ and dry weight of root $\left(\mathrm{r}=0.548^{*}\right)$.

Table 4. Correlation matrix between grain yield and growth parameters of wheat.

\begin{tabular}{|c|c|c|c|c|c|}
\hline & $\begin{array}{l}\text { Plant height } \\
\text { (cm) }\end{array}$ & Root length (cm) & $\begin{array}{l}\text { Fresh weight of } \\
\operatorname{root}(\mathrm{g})\end{array}$ & $\begin{array}{l}\text { Dry weight of } \\
\operatorname{root}(\mathrm{g})\end{array}$ & Grain yield $\left(\mathrm{t} \mathrm{ha}^{-1}\right)$ \\
\hline Plant height $(\mathrm{cm})$ & 1 & $0.566^{*}$ & 0.404 & 0.277 & $0.504 *$ \\
\hline Root length (cm) & $0.566^{*}$ & 1 & 0.302 & 0.197 & 0.374 \\
\hline $\begin{array}{l}\text { Root-fresh weight } \\
(\mathrm{g})\end{array}$ & 0.404 & 0.302 & 1 & $0.850 * *$ & $0.529 *$ \\
\hline Root dry weight (g) & 0.277 & 0.197 & $0.850 * *$ & 1 & $0.548 *$ \\
\hline Grain yield $\left(\mathrm{t} \mathrm{ha}^{-1}\right)$ & $0.504 *$ & 0.374 & $0.529 *$ & $0.548^{*}$ & 1 \\
\hline
\end{tabular}

* Indicates significant at 5\% level of probability

$* *$ Indicates significant at $1 \%$ level of probability 
Table 5. Correlation matrix between grain yield and yield parameters of wheat.

\begin{tabular}{|c|c|c|c|c|c|c|}
\hline & $\begin{array}{l}\text { Spike length } \\
\text { (cm) }\end{array}$ & $\begin{array}{l}\begin{array}{l}\text { Spikelets } \\
\text { spike }^{-1} \text { (no.) }\end{array} \\
\text { (n) }\end{array}$ & $\begin{array}{l}\text { Filled grains } \\
\text { spike }^{-1} \text { (no.) }\end{array}$ & $\begin{array}{l}\text { Unfilled grains } \\
\text { spike }^{-1} \text { (no.) }\end{array}$ & $\begin{array}{l}\text { 1000-grain } \\
\text { weight (g) }\end{array}$ & $\begin{array}{l}\text { Grain yield (t } \\
\text { ha }^{-1} \text { ) }\end{array}$ \\
\hline Spike length $(\mathrm{cm})$ & 1 & $0.518 *$ & 0.444 & -0.357 & $0.541 *$ & 0.382 \\
\hline $\begin{array}{l}\text { Spikelets spike } \\
\text { (no.) }\end{array}$ & $0.518^{*}$ & 1 & $0.844^{* *}$ & $-0.633 * *$ & $0.618^{* *}$ & $0.765^{* *}$ \\
\hline $\begin{array}{l}\text { Filled grains } \\
\text { spike }^{-1} \text { (no.) }\end{array}$ & 0.444 & $0.844 * *$ & 1 & $-0.661 * *$ & $0.687 * *$ & $0.665^{* *}$ \\
\hline $\begin{array}{l}\text { Unfilled grains } \\
\text { spike }^{-1} \text { (no.) }\end{array}$ & -0.357 & $-0.633 * *$ & $-0.661 * *$ & 1 & -0.455 & $-0.631 * *$ \\
\hline $\begin{array}{l}\text { 1000-grain } \\
\text { weight (g) }\end{array}$ & $0.541 *$ & $0.618 * *$ & $0.687 * *$ & -0.455 & 1 & 0.388 \\
\hline $\begin{array}{l}\text { Grain yield } \\
\left(\mathrm{t} \mathrm{h}^{-1}\right)\end{array}$ & 0.382 & $0.765^{* *}$ & $0.665^{* *}$ & $-0.631 * *$ & 0.388 & 1 \\
\hline
\end{tabular}

* Indicates significant at 5\% level of probability

** Indicates significant at $1 \%$ level of probability

\section{Conclusions}

The present study suggests that the use of moringa leaf extract as a foliar spray on wheat had significant positive effects on growth parameters such as plant height, and fresh and dry weight of root and it significantly improved various yield components viz. number of spikelets spike $e^{-1}$ and filled grains spike ${ }^{-1}$. Moringa leaf extract showed a potential in increasing grain and straw yield of wheat under field condition and the highest frequency of moringa application during critical growth stages of crop $\left(\mathrm{T}_{4}\right)$ gave the highest yield. This study suggests the application of MLE at critical growth stages for better growth and yield of performance of wheat when sown late in soil under AEZ 9 (Old Brahmaputra Floodplain) in Bangladesh. However, more research is required to elucidate the novel effect of MLE and moringa plant for development of sustainable agriculture in Bangladesh.

\section{Conflict of interest}

None to declare.

\section{References}

Abbas RN, A Tanveer, A Khaliq, A Iqbal, AR Ghaffari, A Matloob and Q Maqsood, 2013. Maize (Zea mays L.) germination, growth and yield response to foliar application of Moringa oleifera Lam. leaf extracts. Crop Environ., 4: 39-45.

Abdalla MM, 2013. The potential of Moringa oleifera extract as a biostimulant in enhancing the growth, biochemical and hormonal contents in rocket (Eruca vesicaria subsp. sativa) plants. Int. J. Plant Physiol. Biochem., 5: 42-49.

Adebayo AG, HA Akintoye, OO Olufolaji, MT Aina, MT Olatunji and AO Shokalu, 2011. Assessment of organic amendments on vegetative development and nutrient uptake of Moringa oleifera Lam. in the nursery. Asian J. Plant Sci., 10: 74-79.

Afzal MI, MA Iqbal and ZA Cheema, 2015. Triggering growth and boosting economic yield of late-sown wheat (Triticum aestivum L.) with foliar application of allelopathic water extracts. World J. Agril. Sci., 11: 94-100.

Ahmad W, MA Noor, I Afzal, MA Bakhtavar, MM Nawaz, X Sun, B Zhou, W Ma and M Zhao, 2016. Improvement of sorghum crop through exogenous application of natural growth promoting substances under a changing climate. Sustainability, 8: 1330.

Ali Z, SMA Basra, H Munir, A Mahmood and Yousaf A, 2011. Mitigation of drought stress in maize by natural and synthetic growth promoters. J. Agric. Soc. Sci., 7: 56-62.

Anwar F, S Latif, M Ashraf and AH Gilani, 2007. Moringa oleifera. A food plant with multiple medicinal uses. Phytother. Res., 21: 17-25.

BARC (Bangladesh Agricultural Research Council), 2005. Fertilizer Recommendation Guide-2005, BARC, Soils Pub., No. 45, Bangladesh Agril. Res. Council, Farmgate, Dhaka.

BBS (Bangladesh Bureau of Statistics), 2014. Statistical Year Book of Bangladesh. Statistical Division, Ministry of Planning, Govt. People's Republic of Bangladesh, p. 2. 
Chattha MU, MA Sana, H Munir, U Ashraf, I Ul-Haq and SI Zamir, 2015. Exogenous application of plant growth promoting substances enhances the growth, yield and quality of maize (Zea mays L.). Plant Knowledge J., 4: 1-6.

Culver M, F Tagwira and AZ Chiteka, 2013. Effect of moringa extracts on growth and yield of maize and common beans. Greener J. Agri. Sci., 3: 55-62.

Foidle N, HPS Makkar and K Becker, 2001. The potential of Moringa oleifera for agricultural and industrial uses. In: The Miracle Tree: The Multiple Attributes of Moringa. Fuglie LJ. (ed). CTA, Wageningen, The Netherlands, pp. 45-76.

Fuglie LJ, 2000. The Miracle Tree: Moringa oleifera: Natural Nutrition for the Tropics. CTA, Wageningen, The Netherlands, p. 172.

Gomez KA and AA Gomez, 1984. Statistical Procedures for Agricultural Research. John Wiley \& Sons, New York.

Howladar SM, 2014. A novel Moringa oleifera leaf extract can mitigate the stress effects of salinity and cadmium in bean (Phaseolus vulgaris L.) plants. Ecotoxicol. Environ. Saf., 100: 69-75.

Jacob SJP and S Shenbagaraman, 2011. Evaluation of antioxidant and antimicrobial activities of the selected green leafy vegetables. Int. J. Pharm. Tech. Res., 3: 148-152.

Makkar HPS, G Francis and K Becker, 2007. Bioactivity of phytochemicals in some lesser known plants and their effects and potential applications in livestock and aquaculture production systems. Animal, 1: 13711391.

Matthew A, 2016. Moringa leaf extract on the growth and yield of Pepper (Capsicum annuum L.). ARPN J. Agric. Biol. Sci., 11: 107-109.

Mishra G, P Singh, R Verma, S Kumar, S Srivastava, KK Jha and RL Khosa, 2011. Traditional uses, phytochemistry and pharmacological properties of Moringa oleifera plant: An overview. Der Pharmacia Lettre, 3: 141-164.

Moyo B, PJ Masika, A Hugo and V Muchenje, 2011. Nutritional characterization of Moringa (Moringa oleifera Lam.) leaves. Afr. J. Biotechnol., 10: 12925-12933.

Phiri C, 2010. Influence of Moringa oleifera leaf extracts on germination and early seedling development of major cereals. Agric. Biol. J. Amer., 1: 774-777.

Rady MM, GF Mohamed, AM Abdalla and YHM Ahmed, 2015. Integrated application of salicylic acid and Moringa oleifera leaf extract alleviates the salt-induced adverse effects in common bean plants. J. Agric. Tech., 11: 1595-1614.

Siddhuraju $\mathrm{P}$ and $\mathrm{K}$ Becker, 2003. Antioxidant properties of various solvent extracts of total phenolic constituents from three different agro-climatic origins of drumstick tree (Moringa oleifera Lam). J. Agric. Food Chem., 15: 2144-2155.

Yasmeen A, SMA Basra, R Ahmad and A Wahid, 2012. Performance of late sown wheat in response to foliar application of Moringa oleifera Lam. leaf extract. Chil. J. Agric. Res., 72: 92-97.

Yasmeen A, SMA Basra, M Farooq, H Rehman, N Hussain, and HR Athar, 2013. Exogenous application of moringa leaf extract modulates the antioxidant enzyme system to improve wheat performance under saline conditions. Plant Growth Regul., 69: 225-233. 